\title{
Beef heifer fertility: importance of management practices and technological advancements
}

\author{
Sarah E. Moorey ${ }^{1}$ and Fernando H. Biase ${ }^{2^{*}}$ (D)
}

\begin{abstract}
The development of replacement heifers is at the core of cow-calf beef production systems. In 2020, the USDA, National Agricultural Statistics Service reported 5.771 million beef heifers, 500 pounds and over, are under development for cow replacement. A compilation of data from several studies indicate that between $85 \%$ and $95 \%$ of these heifers will become pregnant in their first breeding season. Several thousands of heifers being raised for replacement may not deliver a calf on their first breeding season and result in economic losses to cow-calf producers. Many management procedures have been developed to maximize the reproductive potential of beef heifers. Such approaches include, but are not limited to the following: nutritional management for controlled weight gain, identification of reproductive maturity by physiological and morphological indicators, and the implementation of an estrous synchronization program. The implementation of management strategies has important positive impact(s) on the reproductive efficiency of heifers. There are limitations, however, because some heifers deemed ready to enter their first breeding season do not become pregnant. In parallel, genetic selection for fertility-related traits in beef heifers have not promoted major genetic gains on this particular area, most likely due to low heritability of female fertility traits in cattle. Technologies such as antral follicle counting, DNA genotyping and RNA profiling are being investigated as a means to aid in the identification of heifers of low fertility potential. To date, many polymorphisms have been associated with heifer fertility, but no DNA markers have been identified across herds. Antral follicle count is an indication of the ovarian reserve and is an indicator of the reproductive health of a heifer. We have been working on the identification of transcriptome profiles in heifers associated with pregnancy outcome. Our current investigations integrating protein-coding transcript abundance and artificial intelligence have identified the potential for bloodborne transcript abundance to be used as indicators of fertility potential in beef heifers. In summary, there is an ongoing pressure for reducing costs and increasing efficiency in cow-calf production systems, and new technologies can help reduce the long-standing limitations in beef heifer fertility.
\end{abstract}

Keywords: Beef cattle, Cow-calf, Genomics, Infertility

\footnotetext{
* Correspondence: fbiase@vt.edu

${ }^{2}$ Department of Animal and Poultry Sciences, Virginia Polytechnic Institute and State University, 175 West Campus Drive, Blacksburg, VA 24061, USA

Full list of author information is available at the end of the article
}

(c) The Author(s). 2020 Open Access This article is licensed under a Creative Commons Attribution 4.0 International License, which permits use, sharing, adaptation, distribution and reproduction in any medium or format, as long as you give appropriate credit to the original author(s) and the source, provide a link to the Creative Commons licence, and indicate if changes were made. The images or other third party material in this article are included in the article's Creative Commons licence, unless indicated otherwise in a credit line to the material. If material is not included in the article's Creative Commons licence and your intended use is not permitted by statutory regulation or exceeds the permitted use, you will need to obtain permission directly from the copyright holder. To view a copy of this licence, visit http://creativecommons.org/licenses/by/4.0/. The Creative Commons Public Domain Dedication waiver (http://creativecommons.org/publicdomain/zero/1.0/) applies to the data made available in this article, unless otherwise stated in a credit line to the data. 


\section{Importance of reproductive efficiency in beef cattle production}

A great portion of the expenses in cow-calf production systems is dedicated to the maintenance of healthy cows in productive condition. At the same time, approximately one third of cows removed from the beef herd are eliminated because of reproductive failure $(\sim 33 \%$, NAHMS 2007-2008). Thus, reproductive inefficiency is a limiting factor for the sustainability of beef cattle production systems that leads to financial losses to cattle producers [1].

In cattle, female reproductive failure is assumed when animals do not become pregnant within the breeding season or do not maintain pregnancy to calving [2]. Major female-related causes of reproductive failure include improper health, reproductive and nutritional management, reproductive disorders, and genetics [3-6]. To mitigate some negative factors that impact reproduction, practices associated with cow herd nutrition, healthcare, and reproductive management have been established.

The overall value of a beef female is calculated as the sum of all cash earned over her lifetime minus all expenses. While considerable economic inputs are required to develop replacement heifers, the calves produced throughout a cow's productive lifespan may repay the costs of development and annual maintenance. The payback period is the period of time required for replacement heifers to pay for their development. This period may vary based upon expenses and cow productivity, but may generally be expected that a female must produce 6 calves to pay for her development and maintenance expenses [7]. If the cow fails to calve just 1 year of her productive lifespan, more than 8 calves are required [7], with no recovery of the lost revenue [8].

Another way to consider the profitability of retaining and developing replacement heifers is to calculate net present value (NPV) [7]. Net present value is calculated by accounting for all costs and revenues of the animal over her productive lifespan. Though NPV is heavily influenced by management scheme and calf performance, the reproductive efficiency of a cow greatly influences her NPV. An 11-year-old cow that first calved at age 2 and produced a calf each following year has a higher NPV than a cow that failed to calve 1 year during her productive lifespan [7].

\section{Importance of first breeding season success in replacement heifers}

Heifer reproductive success in the first calving season is highly linked with lifetime reproductive efficiency [911]. A compilation of data from multiple studies demonstrated that first breeding season pregnancy rates in beef heifers range from 64 to $95 \%$ under natural breeding (NB) alone or the combination of artificial insemination (AI) followed by NB ([12-23] (Fig. 1)). Altogether, an average of $85 \%$ of heifers become pregnant by the completion of the breeding season. By comparison, first service conception rates to artificial insemination are lower and range from $36 \%$ to $69 \%[12,14,17,18,20,21,23$, 24]. Our recent analysis of breeding records from 7 yrs (2011-2017) indicated that $43 \%, 42 \%$, and $15 \%$ of heifers became pregnant by $\mathrm{AI}, \mathrm{NB}$, or failed to become pregnant during their first breeding season, respectively [23].

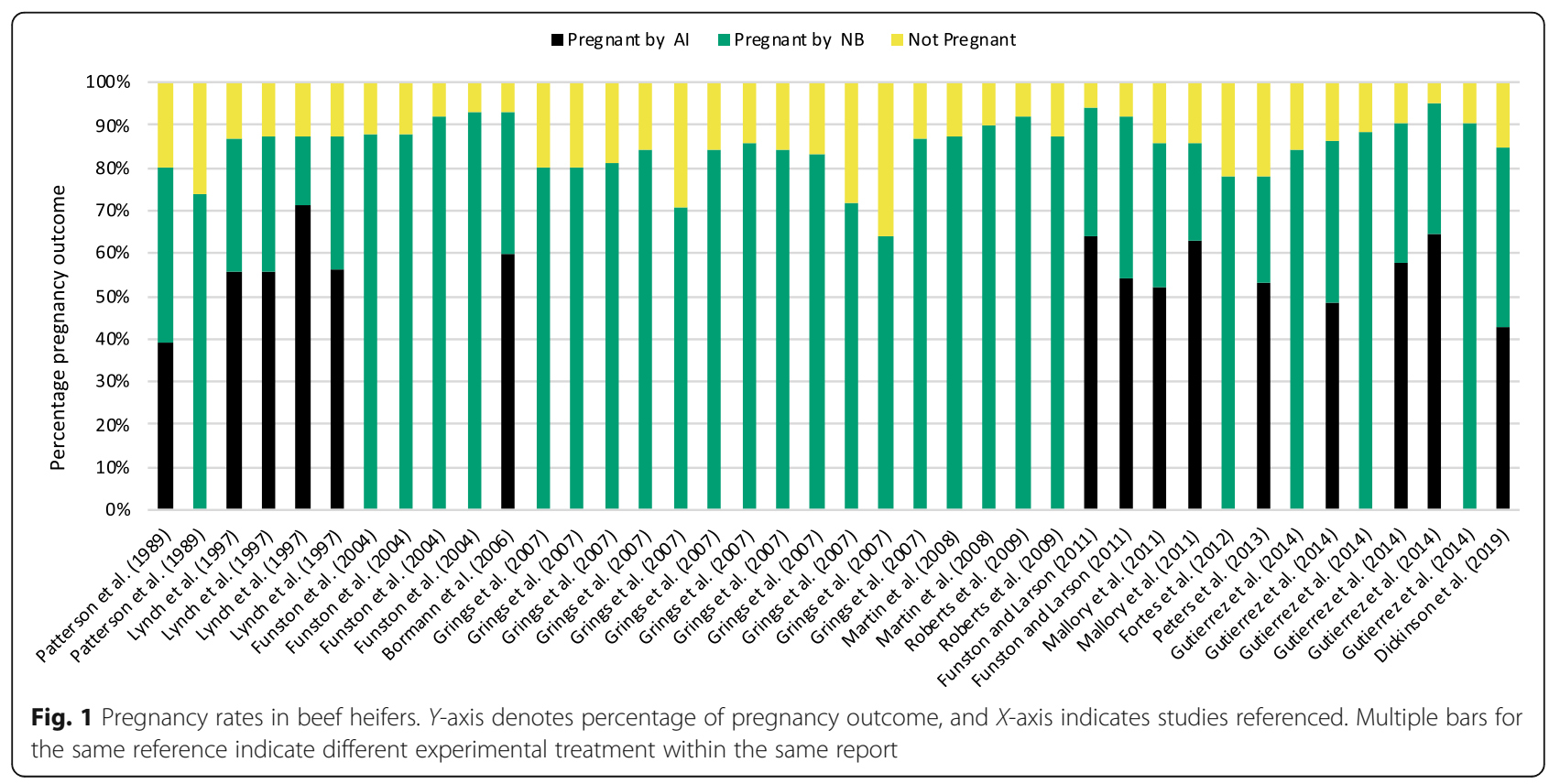


Under current production systems, the most efficient scenario occurs when replacement heifers conceive early in the breeding season. During their first breeding season, $\sim 67 \%, \sim 26 \%$, and $\sim 7 \%$ of heifers that become pregnant are likely to calve during the initial $21 \mathrm{~d}$, between d 22-42, and after d 42 of the subsequent calving season, respectively [11]. Heifers calving within the first $21 \mathrm{~d}$ of their first calving season remain in the productive herd longer and wean more total pounds of calf than their later calving counterparts [11]. In contrast, late breeding heifers contribute to a less efficient cow-calf production system due to reduced days postpartum to resume estrous cyclicity, reduced pregnancy rates in the subsequent calving season, and reductions in calf age and weaning weight $[11,25]$.

Considering the average pregnancy rate $(85 \%)$ obtained from the data compiled in Fig. 1, and accounting for $\sim 5.7$ million heifers being developed as replacements in 2020 (data from National Agricultural Statistics Service, January 2020), one can estimate that approximately 3.3 million heifers will conceive in the first $21 \mathrm{~d}$ of the breeding season. Approximately 1.6 million heifers will conceive later in the breeding season, and over 800 thousand heifers will not produce a calf by $\sim 23-27$ months of age. These numbers underscore a critically large number of heifers that receive important farming resources but do not contribute to a long-term, sustainable production system.

Losses experienced from non-pregnant replacements are the result of opportunity costs of failing to market infertile heifers as feeder calves, wasted nutritional resources, and expenses of breeding and healthcare. If non-pregnant heifers were retained in the herd, such individuals would inevitably represent the negative impacts of a missed calving on NPV and payback period described above. Therefore, non-pregnant replacement heifers are often sold after a failed breeding season.

The costs of development, and reduced lifetime potential profitability, however, lead to a negative economic impact for cattle producers. Therefore, extra costs for heifer development due to losses when some heifers fail to become pregnant must be accounted for [26]. Depending on replacement heifer management system, these added costs can equate to $\sim \$ 43$ per replacement heifer developed to the time of pregnancy examination, as estimated by Hughes [26]. Considering the $\sim 5.7$ million heifers expected to enter replacement development in 2020, such cost might exceed $\$ 245$ million nationwide. It must be pondered, however, that extra expenses caused by infertility can be reduced if the initial investment in heifer development is not extreme [13].

The economic impact of the reduced age of calves from late breeding heifers is also considerably high. Considering market prices of $\sim \$ 1.65$ per pound (USDA,
Agriculture Marketing Service; Joplin Regional Stockyards; Feb 17, 2020; average prices of steer and heifer calves of $\sim 450 \mathrm{lb}$.) and an average daily gain of $\sim 1.90 \mathrm{lb}$. per day $[27,28]$, calves born at the midpoint of the second and third $21 \mathrm{~d}$ of the calving season would be worth approximately $\$ 131$ less than calves born on the first day of the calving season. When this number is multiplied by the 1.6 million heifers expected to conceive late in their first breeding season, one can account for over $\$ 210$ million lost by beef cattle producers due to late breeding heifers. These numbers underscore reproductive inefficiency among the major limiting biological functions significantly affecting the beef cattle industry.

The yearly cost of female infertility varies with the commodity value but remains unacceptably high under the current economic scenario. Since the early 1970s, it has been established that improving pregnancy rates is paramount for the development and maintenance of efficient and sustainable beef cattle production [29]. Since then, there have been major advancements to our understanding of the reproductive physiology of beef heifers and the identification of means to address reproductive inefficiency.

\section{Management practices to improve beef heifer reproductive success}

The proper selection and development of replacement heifers enhances the likelihood that heifers entering development programs will conceive early in the breeding season followed by increased stayability [30]. Management strategies aimed at increasing first breeding season reproductive success are discussed below, and many are targeted towards increasing the percentage of heifers reaching puberty before the start of the breeding season. Such practices include the selection of older and heavier heifers at weaning [31], nutritional management of heifers to reach a defined percentage of their mature bodyweight by the start of the breeding season $[16,22]$, reproductive tract scoring to screen heifers for puberty $\sim 30 \mathrm{~d}$ before the start of the breeding season [18], the implementation of a progestin-based estrous synchronization protocol $[18,32]$, and the incorporation of expected progeny differences (EPDs) to select heifers with increased genetic merit for fertility.

\section{Age of heifers}

The selection of replacement heifers that are born early in the calving season is an essential step to optimizing overall reproductive success. It is expected that early born heifers will enter the breeding season with increased morphological and physiological maturity than their younger herd mates.

In a study by Funston and colleagues, heifers born in the first $21 \mathrm{~d}$ of the calving season were heavier at prebreeding than heifers born in the second or third period 
of the calving season (296, 292 and $276 \mathrm{~kg}$, respectively, [31]). Additionally, $70 \%$ of early born heifers were cycling by the start of their first breeding season, compared to $58 \%$ and $30 \%$ of heifers born in the second and third 21-d period, respectively. As a consequence, older heifers presented greater pregnancy rates (90\%) compared to 86 and $78 \%$ for heifers that were born in consecutive 21-d windows of the calving period, respectively [31]. Our analysis of breeding records from Angus $\times$ Simmental crossbred heifers indicated that heifers older than $368 \mathrm{~d}$ of age at the beginning of the breeding season had $87.5 \%$ chance of becoming pregnant within $90 \mathrm{~d}$ compared to a $12.5 \%$ chance if the heifer was younger [23].

Heifers from different breeds reach puberty at different ages, ranging from 10 to 14 months, with crossbred heifers usually displaying estrus at an earlier age than purebreds [33-37]. These investigations also revealed that within a cohort of heifers of similar genetic makeup, some individuals will reach puberty early or late relative to their counterparts. Directly related to their age and physiological maturity, among cycling heifers, older heifers that are bred on their third estrous cycle present greater pregnancy rates $(78 \%)$ relative to counterparts that are bred on their first estrous cycle (57\%; [37]). Additionally, heifers entering the breeding season before reaching puberty or after one estrous cycle had reduced calving rates within the first $21 \mathrm{~d}$ of their first calving season compared to heifers experiencing at least 2 cycles before the onset of breeding [38].

Older heifers have a greater chance to become pregnant in their first breeding season. Nonetheless, it is critical that an appropriate balance is achieved for heifers to calve around 24 months of age, as these individuals will have a greater overall calving output relative to later breeding heifers [11, 39].

\section{Nutritional management of heifers}

Appropriate nutritional status is essential for reproductive success in cattle. Energy restriction delays the ever critical onset of puberty in beef replacement heifers [40, 41]. Furthermore, inadequate energy consumption, as exhibited by low body condition score, reduces pregnancy success in beef cows throughout their productive lifespan [42]. By contrast, heifers experiencing higher levels of nutrition and adequate weight gain prior to the first breeding season experience increased reproductive success in their first and subsequent calving seasons [43, 44]. To this end, heifer development programs have been established for beef cattle producers to provide adequate nutrition for heifers to attain puberty and high reproductive success in their first breeding season. Cattle farms in different regions have varied sources of nutrients available for heifer development, and these feedstuffs have seasonal availability. Thus, the impact of the timing of weight gain on first breeding season pregnancy outcome has been evaluated.

No statistical differences in the percentage of heifers reaching puberty, becoming pregnant in the first or second $21 \mathrm{~d}$ of the breeding season, or conceiving by the end of the breeding season were observed among heifers managed to gain at a steady rate $(0.45 \mathrm{~kg} / \mathrm{d})$, to gain none and then rapidly $(0.91 \mathrm{~kg} / \mathrm{d})$, or to gain rapidly $(0.91 \mathrm{~kg} / \mathrm{d})$ and then none during development from 45 $\mathrm{d}$ post-weaning to the start of the breeding season [45]. Heifers developed at a steady rate, however, had first service pregnancy rates of $62 \%$ as compared to $47 \%$ and $35 \%$ in fast-slow or slow-fast gaining heifers, respectively [45]. In a similar study, heifers that gained $0.11 \mathrm{~kg} / \mathrm{d}$ initially, followed by $0.91 \mathrm{~kg} / \mathrm{d}$ had similar first service conception rates and overall pregnancy rates when compared to heifers developed to gain weight at a constant $0.45 \mathrm{~kg} / \mathrm{d}$ throughout the peri-pubertal period [20]. Nutritional management of heifers to gain weight in a stairstep fashion (fast gain, followed by slow gain, followed by fast gain immediately before breeding) yielded similar breeding season pregnancy rates as developmental programs with consistent gains [35, 46].

The timing of weight gain has minimal consequence for heifer fertility, but the weight a heifer reaches by the start of her first breeding season heavily impacts her reproductive success. Patterson and others demonstrated greater pregnancy rates when heifers reached $65 \%$ versus $55 \%$ of their mature body weight by the start of the breeding season [22]. Since then, reduced rates of puberty, but no difference in breeding season pregnancy rates have been reported in heifers managed to reach $55-56 \%$ versus $58-60 \%$ of their mature bodyweight [13, $16,17]$. Pregnancy rate to artificial insemination tended to be reduced in heifers developed to $55 \%$ [13], but was not reduced in heifers developed to $56 \%$ of mature body weight [17]. The development of heifers to $50 \%$ versus $55 \%$ of mature bodyweight also yielded no difference in overall 45-d breeding season pregnancy rates, but significantly delayed the date of first calving [19].

A large body of data reinforce the concept that heifers should be developed to reach a minimum percentage of their anticipated mature body weight by the start of the breeding season. It must be noted, however, that the target weight depends on heifer genetic makeup [47], nutritional management program, and breeding protocols utilized.

Inarguably, the feed source must be accounted when developing heifers to a target weight tailored to a particular cow-calf operation. For instance, the utilization of pasture, dormant range, or crop residues may provide valuable options for heifer development outside of the feedlot. Overall feed costs, total development costs, and net costs per pregnant heifer were significantly lower 
when heifers were developed to a lower bodyweight on forage diets than when heifers were developed solely in a dry lot $[17,48]$.

\section{Implementation of reproductive tract scores}

The physiological and morphological maturity of the reproductive system is achieved as heifers attain puberty, but not all animals reach appropriate developmental status by the beginning of the breeding season. A reproductive tract scoring system ranging from 1 (prepubertal, infantile tract) to 5 (pubertal, corpus luteum present) was developed to categorize heifers according to uterine and ovarian development as determined by rectal palpation [49]. Usually, reproductive tract scoring is performed four to six weeks before the start of the heifer's first breeding season and has become a tool to indicate the reproductive readiness of beef heifers.

Several independent reports have demonstrated that there is a strong, nearly linear relationship between reproductive tract score and pregnancy rates (Fig. 2). Lower scores (1 and 2) are consistently associated with lower pregnancy rates, whereas scores 4 and 5 indicate heifers that are cycling and therefore have greater pregnancy rates whether bred by AI alone or following a breeding season of AI followed by natural service [18, $23,24,47,50]$. Most cattle operations in the US may expect a majority of heifers to reach a reproductive tract score greater than 3 by the start of the breeding season. Reproductive tract scoring, however, remains an important tool to identify reproductively immature heifers or morphological abnormalities prior to breeding.

\section{Implementation of a progestin-based protocol for} synchronization of estrus

Progestins can be used to induce puberty in peripubertal heifers and were initially used with estradiol to simulate the hormonal changes associated with the acquisition of puberty [51, 52]. Such changes begin with the increased progesterone levels associated with pubertal development in heifers [53]. The utilization of a progestin mimics this rise in progesterone and then allows for increased luteinizing hormone pulse frequency and desensitized negative feedback effects of estradiol on gonadotropin releasing hormone $(\mathrm{GnRH})$ secretion $[54,55]$. Therefore, peripubertal heifers experience increased follicular growth and estradiol production associated with fertile estrus and ovulation $[54,56]$.

There is an additional benefit from progestin-based protocols, whether through the utilization of a controlled internal drug release (CIDR; [57]) insert or melengestrol acetate (MGA; [58]). Such protocols synchronize ovulation in heifers and allow all heifers to be inseminated on day one of the breeding season. Overall, progestin based synchronization programs have a positive influence on heifer calving date and breeding season pregnancy rates $[18,19,32,59]$.

\section{The genetic basis of heifer fertility}

Genetic selection is used to improve beef cattle populations for many production related traits. Relatively fast genetic progress can be achieved with traits such as growth rate and carcass quality because of their moderate to high heritability [60-62]. By contrast, the heritability of traits directly related to female reproduction is

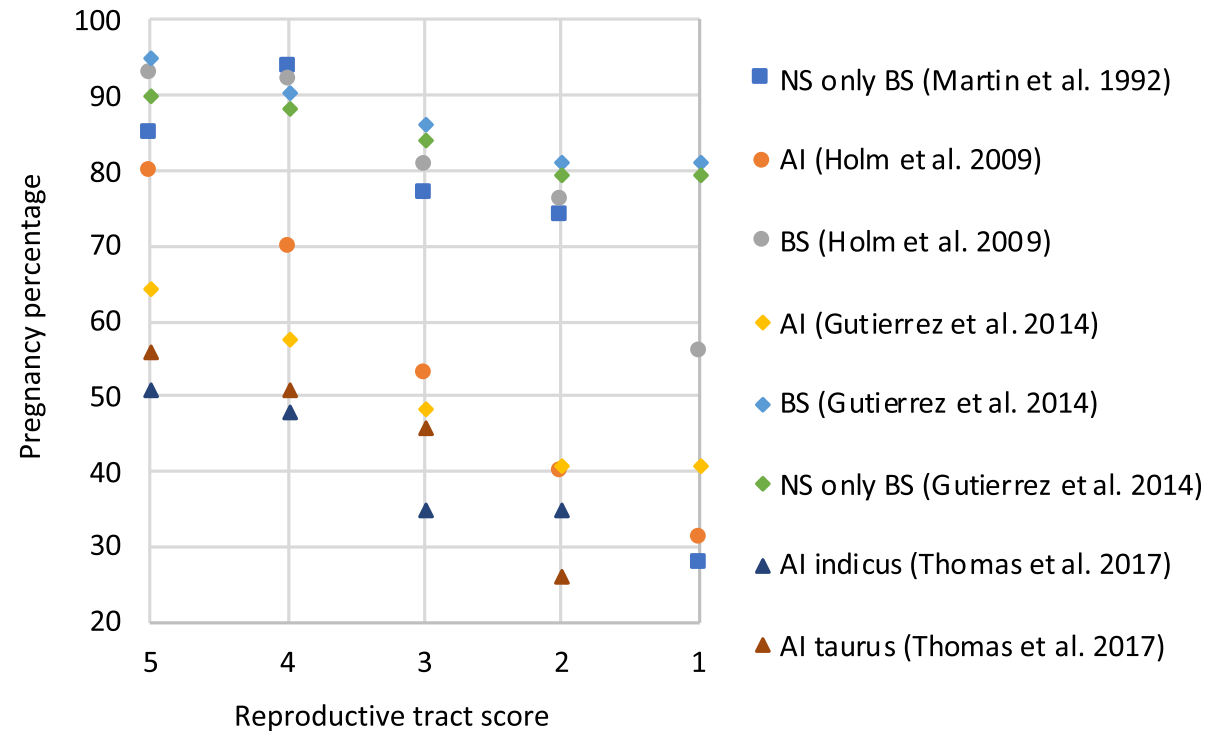

Fig. 2 Pregnancy rates in beef heifers of different reproductive tract scores. $Y$-axis denotes pregnancy percentage, and $X$-axis denotes reproductive tract score categories. Al: artificial insemination, BS: breeding season, NB: natural breeding, indicus: B. indicus, taurus: B. taurus 
lower, and thus the rate of genetic change in fertility traits based upon genetic selection is much slower relative to growth and carcass traits. Despite low heritability, models are being developed utilizing genetic parameters to select beef cattle for the improvement of heifer fertility.

Pregnancy rate is a common trait utilized when evaluating fertility. Interestingly, the genetic correlation between yearling pregnancy rate and lifetime pregnancy rate is high, namely $0.92-0.97[9,10]$. These findings support a genetic link between reproductive success in the first breeding season and productive lifespan, however the genes and genetic models of this correlation are yet to be unveiled.

The genetics of heifer pregnancy rate, or the likelihood of pregnancy within the first breeding season, is valuable to select heifers with increased genetic merit for pregnancy success. Genetic progress is limited because the heritability of heifer pregnancy rate ranges from 0.07 to $0.20[12,14,61,63-66]$. First-service conception rate is another trait evaluated when considering heifer genetic merit for fertility. First-service conception rate identifies animals conceiving to their first service separately from animals conceiving later in the breeding season. The heritability of first-service conception in heifers is also low, ranging from 0.03 to 0.18 [12, 14, 61]. Altogether, diverse reports consistently indicate that pregnancy in beef heifers is controlled by a small portion of the additive component of a heifer's genetic makeup.

Beef cattle production systems have greatly benefited from heterosis, but the investigations of heterosis on heifer fertility are scarce. Cundiff and others identified that crossbred heifers had $6.6 \%$ greater conception rate to natural service followed by $6.4 \%$ increase in calf crop weaned [67]. MacNeil and others observed that purebred or linecross heifers presented $76.2 \%$ and $79.4 \%$ pregnancy rates, respectively, but both groups had similar calf birth rates at $77 \%$ [68]. The effect of heterosis on heifer pregnancy is uncertain, but crossbreeding does influence heifer prebreeding weight and anticipated puberty onset [47].

\section{Current and emerging technologies for assessing fertility in heifers}

The proper development of replacement heifers and the utilization of expected progeny differences for traits such as heifer pregnancy, first service conception rate, stayability, and scrotal circumference to select animals with superior genetics for fertility can improve heifer pregnancy rates. The impact of these means of selection and development eventually reach a plateau. Therefore, more detailed analyses of the phenotypic, physiological, and genetic components of heifer fertility are necessary. To this end, studies examining differences in genotypes, transcriptome profiles, and physical indicators of the ovarian reserve have been explored. As such, scientists have begun to reveal deep variations in otherwise phenotypically normal heifers of similar genetic background with remarkable contrasts in fertility potential. There is exciting opportunity for the utilization of many of these approaches to not only increase understanding of heifer fertility, but to identify additional parameters for the selection of highly fertile heifers.

\section{Antral follicle count}

There is evidence that the selection of highly fertile heifers as replacement females may be improved with selection based upon antral follicle counts [69, 70]. In cattle, the oocyte and its surrounding follicle develop during fetal growth, with the presence of primordial follicles occurring by day 74-110 of gestation [71, 72]. Follicles remain quiescent at the primordial follicle stage until they are activated to the primary follicle stage and progress into the pre-antral and antral stages of follicular development [71, 72]. Antral follicles are then recruited into follicular waves that occur throughout the bovine estrous cycle [73]. The number of antral follicles present during a follicular wave can be determined by ultrasonography, in which the number of follicles $\geq 3 \mathrm{~mm}$ is reported as the antral follicle count (AFC).

Antral follicle counts are highly variable among animals, yet highly repeatable within an individual animal, allowing animals to be classified according to AFC [74]. Furthermore, AFC accurately depicts the ovarian reserve of cattle, in which animals with a low AFC possess less healthy primordial, pre-antral, and antral follicles compared to animals with high AFCs [75].

The ovarian reserve is related to fertility in female mammals. Cows with high AFC had higher pregnancy rates and shorter postpartum periods than animals with low AFCs [76]. Furthermore, AFC is associated with luteal and uterine function in cattle, and increased AFC was associated with higher reproductive success in beef heifers $[69,70]$. A study of 47 young adult beef cattle and late lactation dairy cattle revealed that animals with low AFC had poorer endometrial development, followed by progesterone concentrations $30-50 \%$ lower than animals with high AFC [77].

Differences in oocyte competence have also been observed between animals with high versus low AFC. Ireland et al. [75] reported greater abundance of cathepsin mRNA in cumulus cells and increased intrafollicular estradiol concentrations in animals with low AFC, both of which are associated with reduced oocyte competence. Antral follicle counts hold great promise for improving replacement heifer selection criteria as they are determined though non-invasive procedures and are correlated with reproductive success in cattle. 


\section{DNA polymorphisms}

The ability to analyze thousands of single nucleotide polymorphisms (SNPs) allows researchers to investigate complex traits related through genome wide association studies (GWAS). Multiple studies have identified SNPs significantly associated with traits known to influence reproductive success in beef heifers, such as age at puberty $[78,79]$.

Peters and others identified twelve chromosomal regions associated with first service conception and six regions associated with heifer pregnancy [14]. Many of the regions containing SNPs associated with first service conception and heifer pregnancy corresponded to previously identified regions related to age at first corpus luteum [78]. Additionally, two regions on BTA2 and BTA8 were identified to have a relationship with heifer pregnancy. Single nucleotide polymorphisms identified on chromosome two were in close proximity to previously identified quantitative trait loci associated with differences in growth, carcass, lactation, and feed efficiency [62]. Such results support the importance of systems targeted research that considers the interconnectivity of animal body condition, growth, and reproductive outcome.

McDaneld and others identified SNPs associated with varied levels of reproductive success in B. taurus purebred, B. taurus $\times B$. taurus crossbred, and B. taurus $\times B$. indicus crossbred animals [80]. Due to the utilization of multiple populations of animals, individuals were either ranked for fertility upon reproductive outcomes in the first five breeding seasons or indicated as pregnant or open based on pregnancy success in the first or multiple breeding seasons. A single SNP on BTA29 achieved genome wide significance or nominal significance in some test populations. Interestingly, this SNP was within 786 $\mathrm{kb}$ of a SNP previously indicated to be associated with age at first identified corpus luteum in tropically adapted heifers [78]. Five additional SNPs on BTA1, BTA5, and BTA25 were identified at a suggestive level of significance in at least one population of animals. Single nucleotide polymorphisms on BTA5 coincided with previously reported SNPs associated with age at first corpus luteum, length of postpartum anestrous period, and the incidence of corpus luteum before calf weaning [78].

Additionally, presence of $\mathrm{Y}$ chromosome material was identified in low fertility and open classified heifers in the populations described above [81]. Approximately $18-29 \%$ of the heifers determined to have low fertility or failing to become pregnant, respectively, tested positive for segments of the bovine Y-chromosome.

Quantitative trait loci and gene networks were also identified in beef heifers previously classified as having high or sub-fertility based on d 28 pregnancy outcomes to serial embryo transfer [82]. Fourteen loci were strongly associated with heifer fertility, while eight loci displayed moderate association. Of these loci, five had positional candidate genes with previously indicated functions in fertility and uterine receptivity to pregnancy. One remarkable example is the gene kinesin family member $4 \mathrm{~A}$ (KIF4A), which was located within the most significant locus associated with heifer fertility. Previous studies indicated elevated levels of KIF4A in endometrium samples collected on day seven post estrus in Simmental heifers who established pregnancy to embryo transfer following the next observed estrus compared to those that failed to establish pregnancy [83].

Investigations have also been conducted to understand fertility in $B$. indicus cattle, with emphasis on Nellore heifers. Many of these studies focused on identifying markers associated with heifers becoming pregnant by 14-16 months of age. Using a targeted approach, Camargo and others identified possible polymorphisms in the gene JY-1, an oocyte specific protein, associated with the probability of pregnancy by 16 months of age [84]. Several polymorphisms of interest for heifer fertility in zebu cattle were unveiled via GWAS analysis. Dias and others identified three haplotypes significantly associated with heifer pregnancy, which contained the genes fatty acid binding protein 4 (FABP4) and protein phosphatase 3 catalytic subunit alpha (PPP3CA) [85]. Focusing on chromosomic regions, two studies identified chromosome regions that explained as much as $8.91 \%$ [86] and $12.73 \%$ [87] of the variance in sexual precocity to become pregnant by 16 months of age and heifer pregnancy, respectively. Of note, both studies identified windows on chromosomes 5,14 , and 18 , with a potential overlap on chromosome 14 [86, 87]. Takada and others focused on haplotypes encompassing 125 candidate genes and identified nine haplotypes with significant association with early pregnancy. Those haplotypes were located in the genes pregnancy-associated plasma protein-A2 (PAPP-A2), estrogen-related receptor gamma (ESRRG), pregnancyassociated plasma protein-A (PAPP-A), kell blood group complex subunit-related family (XKR4), and mannosebinding lectin (MBL-1) [88].

The Animal QTL database holds curated and compiled data on hundreds of DNA markers associated with diverse traits in livestock, including cattle [89]. The database currently has information on 56 markers associated with heifer pregnancy rate (Table 1). Throughout this selected data from the Animal QTL Database, and data from studies not identified in the database, it is important to notice that there is no clear redundancy of markers identified across studies. This observation points to the critical aspect of the replicability of the findings across populations [91] in addition to the complexity and most likely omnigenic nature of fertility. 
Table 1 Quantitative trait loci present in the Animal QTL Database associated with beef heifer pregnancy ${ }^{\mathrm{a}}$

\begin{tabular}{|c|c|c|c|c|c|c|c|}
\hline QTL ID & Chr & Range, cM & Flank mark A & Peak mark & Flank mark B & Reference & Candidate gene symbol \\
\hline 137,399 & 1 & $\mathrm{Na}$ & $\mathrm{Na}$ & rs108940570 & $\mathrm{Na}$ & Regatieri et al. [90] & $A P P$ \\
\hline 151,129 & 1 & $119.14-120.06$ & rs136647907 & $\mathrm{Na}$ & rs133111309 & Júnior et al. [87] & $\mathrm{Na}$ \\
\hline 22,901 & 2 & $38.77-39.71$ & rs42919869 & $\mathrm{Na}$ & rs43307553 & Peters et al. [14] & $\mathrm{Na}$ \\
\hline 151,122 & 2 & $49.04-49.84$ & rs42509691 & $\mathrm{Na}$ & rs134051905 & Júnior et al. [87] & $\mathrm{Na}$ \\
\hline 151,125 & 2 & $52.56-53.43$ & rs133912634 & $\mathrm{Na}$ & rs134084039 & Júnior et al. [87] & $\mathrm{Na}$ \\
\hline 151,131 & 3 & $2.94-3.91$ & rs109945234 & $\mathrm{Na}$ & rs42368646 & Júnior et al. [87] & $\mathrm{Na}$ \\
\hline 22,902 & 4 & $3.97-4.89$ & rs110197100 & $\mathrm{Na}$ & rs1 10954467 & Peters et al. [14] & $\mathrm{Na}$ \\
\hline 151,119 & 5 & $\mathrm{Na}$ & rs42917128 & $\mathrm{Na}$ & rs136339681 & Júnior et al. [87] & $\mathrm{Na}$ \\
\hline 107,840 & 5 & $10.23-11.66$ & $\mathrm{Na}$ & $\mathrm{Na}$ & $\mathrm{Na}$ & Irano et al. [86] & $\mathrm{Na}$ \\
\hline 108,449 & 5 & $18.49-19.71$ & $\mathrm{Na}$ & $\mathrm{Na}$ & $\mathrm{Na}$ & Irano et al. [86] & $\mathrm{Na}$ \\
\hline 151,128 & 5 & $56.06-57.01$ & rs110797637 & $\mathrm{Na}$ & rs137576699 & Júnior et al. [87] & $\mathrm{Na}$ \\
\hline 151,121 & 5 & 78.99-80.01 & rs137127461 & $\mathrm{Na}$ & rs109435449 & Júnior et al. [87] & $\mathrm{Na}$ \\
\hline 151,113 & 5 & $80.05-81.09$ & rs109437025 & $\mathrm{Na}$ & rs1 10687761 & Júnior et al. [87] & $\mathrm{Na}$ \\
\hline 151,114 & 5 & $84.41-85.50$ & rs42561706 & $\mathrm{Na}$ & rs137385583 & Júnior et al. [87] & $\mathrm{Na}$ \\
\hline 151,115 & 5 & $88.95-89.84$ & rs110496647 & $\mathrm{Na}$ & rs136544553 & Júnior et al. [87] & $\mathrm{Na}$ \\
\hline 151,124 & 5 & 89.94-90.94 & rs110450288 & $\mathrm{Na}$ & rs133794376 & Júnior et al. [87] & $\mathrm{Na}$ \\
\hline 119,777 & 6 & $12.13-13.29$ & $\mathrm{Na}$ & $\mathrm{Na}$ & $\mathrm{Na}$ & Irano et al. [86] & $\mathrm{Na}$ \\
\hline 57,465 & 6 & $28.43-28.44$ & rs134077806 & $\mathrm{Na}$ & rs134383126 & Dias et al. [85] & РРРЗСА \\
\hline 57,466 & 6 & $28.54-28.54$ & rs109697066 & $\mathrm{Na}$ & rs137526343 & Dias et al. [85] & РРРЗСА \\
\hline 119,778 & 7 & $3.77-4.65$ & $\mathrm{Na}$ & $\mathrm{Na}$ & $\mathrm{Na}$ & Irano et al. [86] & $\mathrm{Na}$ \\
\hline 119,779 & 7 & $49.92-50.82$ & $\mathrm{Na}$ & $\mathrm{Na}$ & $\mathrm{Na}$ & Irano et al. [86] & $\mathrm{Na}$ \\
\hline 22,903 & 8 & $0.40-1.10$ & rs110007458 & $\mathrm{Na}$ & rs111021990 & Peters et al. [14] & $\mathrm{Na}$ \\
\hline 152,647 & 8 & 115.08-115.08 & rs135042546 & $\mathrm{Na}$ & rs1 10990932 & Takada et al. [88] & PAPPA \\
\hline 22,904 & 10 & $103.21-104.31$ & rs43647342 & $\mathrm{Na}$ & rs41657367 & Peters et al. [14] & $\mathrm{Na}$ \\
\hline 22,905 & 13 & $99.13-100.27$ & rs110209373 & $\mathrm{Na}$ & rs41660868 & Peters et al. [14] & $\mathrm{Na}$ \\
\hline 151,116 & 14 & $28.67-29.98$ & rs41724652 & $\mathrm{Na}$ & rs133297141 & Júnior et al. [87] & $\mathrm{Na}$ \\
\hline 152,648 & 14 & $30.64-30.66$ & rs42646650 & $\mathrm{Na}$ & rs134214692 & Takada et al. [88] & XKR4 \\
\hline 119,780 & 14 & $29.53-30.56$ & $\mathrm{Na}$ & $\mathrm{Na}$ & $\mathrm{Na}$ & Irano et al. [86] & $\mathrm{Na}$ \\
\hline 151,127 & 14 & $31.34-32.62$ & rs135852767 & $\mathrm{Na}$ & rs42298467 & Júnior et al. [87] & $\mathrm{Na}$ \\
\hline 151,118 & 14 & $36.75-37.97$ & rs41624840 & $\mathrm{Na}$ & rs136805030 & Júnior et al. [87] & $\mathrm{Na}$ \\
\hline 57,464 & 14 & $61.17-61.17$ & rs132819090 & $\mathrm{Na}$ & rs109077068 & Dias et al. [85] & FABP4 \\
\hline 152,641 & 16 & $25.33-25.36$ & rs136930654 & $\mathrm{Na}$ & rs132925189 & Takada et al. [88] & ESRRG \\
\hline 152,642 & 16 & $25.65-25.67$ & rs133536959 & $\mathrm{Na}$ & rs109979901 & Takada et al. [88] & ESRRG \\
\hline 152,643 & 16 & $73.28-73.35$ & rs136672059 & $\mathrm{Na}$ & rs109160879 & Takada et al. [88] & PAPPA2 \\
\hline 152,644 & 16 & 73.35-73.38 & rs135370722 & $\mathrm{Na}$ & rs132969356 & Takada et al. [88] & PAPPA2 \\
\hline 152,645 & 16 & 73.39-73.41 & rs132814943 & $\mathrm{Na}$ & rs42300953 & Takada et al. [88] & PAPPA2 \\
\hline 152,646 & 16 & $73.56-73.66$ & rs132776805 & $\mathrm{Na}$ & rs41814719 & Takada et al. [88] & PAPPA2 \\
\hline 151,117 & 18 & $\mathrm{Na}$ & rs136460244 & $\mathrm{Na}$ & rs41891085 & Júnior et al. [87] & $\mathrm{Na}$ \\
\hline 119,781 & 18 & $5.63-6.48$ & $\mathrm{Na}$ & $\mathrm{Na}$ & $\mathrm{Na}$ & Irano et al. [86] & $\mathrm{Na}$ \\
\hline 22,906 & 20 & $81.03-82.15$ & rs41959108 & $\mathrm{Na}$ & rs110359079 & Peters et al. [14] & $\mathrm{Na}$ \\
\hline 137,400 & 21 & $\mathrm{Na}$ & $\mathrm{Na}$ & rs134589009 & $\mathrm{Na}$ & Regatieri et al. [90] & $\mathrm{Na}$ \\
\hline 137,401 & 21 & $\mathrm{Na}$ & $\mathrm{Na}$ & rs134601255 & $\mathrm{Na}$ & Regatieri et al. [90] & SETD3 \\
\hline 119,782 & 21 & $0.01-3.77$ & $\mathrm{Na}$ & $\mathrm{Na}$ & $\mathrm{Na}$ & Irano et al. [86] & $\mathrm{Na}$ \\
\hline 119,783 & 21 & $77.11-77.86$ & $\mathrm{Na}$ & $\mathrm{Na}$ & $\mathrm{Na}$ & Irano et al. [86] & $\mathrm{Na}$ \\
\hline
\end{tabular}


Table 1 Quantitative trait loci present in the Animal QTL Database associated with beef heifer pregnancy ${ }^{\text {a }}$ (Continued)

\begin{tabular}{|c|c|c|c|c|c|c|c|}
\hline QTL ID & Chr & Range, cM & Flank mark A & Peak mark & Flank mark B & Reference & Candidate gene symbol \\
\hline 137,402 & 22 & $\mathrm{Na}$ & $\mathrm{Na}$ & rs133503069 & $\mathrm{Na}$ & Regatieri et al. [90] & ARHGEF3 \\
\hline 151,123 & 24 & $61.41-62.40$ & rs109329309 & $\mathrm{Na}$ & rs135881583 & Júnior et al. [87] & $\mathrm{Na}$ \\
\hline 151,120 & 24 & 70.77-71.92 & rs136828522 & $\mathrm{Na}$ & rs137238317 & Júnior et al. [87] & $\mathrm{Na}$ \\
\hline 119,784 & 27 & $1.83-2.91$ & $\mathrm{Na}$ & $\mathrm{Na}$ & $\mathrm{Na}$ & Irano et al. [86] & $\mathrm{Na}$ \\
\hline 152,649 & 28 & $50.38-50.38$ & rs136285814 & $\mathrm{Na}$ & rs133640737 & Takada et al. [88] & $\mathrm{Na}$ \\
\hline 31,164 & 29 & $18.28-18.48$ & $\mathrm{Na}$ & $\mathrm{Na}$ & $\mathrm{Na}$ & de Camargo et al. [84] & $J Y-1$ \\
\hline 31,165 & 29 & $18.28-18.48$ & $\mathrm{Na}$ & $\mathrm{Na}$ & $\mathrm{Na}$ & de Camargo et al. [84] & $J Y-1$ \\
\hline 31,166 & 29 & $18.28-18.48$ & $\mathrm{Na}$ & $\mathrm{Na}$ & $\mathrm{Na}$ & de Camargo et al. [84] & $J Y-1$ \\
\hline 31,167 & 29 & $18.28-18.48$ & $\mathrm{Na}$ & $\mathrm{Na}$ & $\mathrm{Na}$ & de Camargo et al. [84] & $J Y-1$ \\
\hline 151,130 & 29 & $33.02-34.37$ & rs134769207 & $\mathrm{Na}$ & rs42172278 & Júnior et al. [87] & $\mathrm{Na}$ \\
\hline 151,126 & $x$ & $\mathrm{Na}$ & rs134685381 & $\mathrm{Na}$ & rs137716652 & Júnior et al. [87] & $\mathrm{Na}$ \\
\hline 151,132 & $x$ & $64.37-65.63$ & rs134673004 & $\mathrm{Na}$ & rs134676523 & Júnior et al. [87] & $\mathrm{Na}$ \\
\hline
\end{tabular}

a The completeness of the database is dependent on the submission of data by researchers; Na: not available

\section{Promise for the development of bloodborne indicators of heifer fertility}

Recent studies have demonstrated that the profiling of circulating biological features (hormones, metabolites, transcripts, or epigenetic marks on the DNA of circulating cells) is revealing of the physiological state of an individual [92]. The analysis of multiple layers of an individual's molecular blueprint is likely key for the understanding of several complex traits, in a health context and otherwise [93]. The systemic profiling of circulating biological features is likely to also contribute to the understanding of infertility [94].

\section{Bloodborne mRNA profiles}

Considering that the physiology of an individual is highly linked to molecular features circulating in the bloodstream and the relationships of peripheral blood natural killer cells with fertility in women, we reasoned that mRNA profiles of peripheral white blood cells (PWBC) may differ among beef heifers who became pregnant to $\mathrm{AI}$, pregnant to $\mathrm{NB}$, and failed to become pregnant in their first breeding season. Our first profiling of mRNA transcripts from heifers from different pregnancy outcomes revealed six DEGs (ALAS2, CNKSR3, LOC522763, SAXO2, TAC3, TFF2, FDR $<0.05$ ) between heifers that became pregnant to $\mathrm{AI}$ and heifers that did not become pregnant [95]. In a follow up experiment, we identified 67 DEGs $(\mathrm{FDR}<0.03)$ between AI-pregnant and non-pregnant heifers.

A natural question is whether we can use gene expression profiles to distinguish phenotypes. To this end, we analyzed our data using top scoring pair approach and revealed two gene pairs (C11orf54, TAF1B; URB2, ENST AG00000039129) whose relative expression within heifers discriminated most AI-pregnant (10 out of 12) from the other heifers profiled [95]. In a subsequent study, we applied machine learning algorithms on data obtained from two breeding seasons. The data from year 2015/2016 was used to train the algorithms and the data from 2016/2017 was used for blind predictions and assessment of model accuracy. The heifers in the test data were classified with $100 \%$ of accuracy in $46.3 \%$ out of 2000 randomizations), followed by $53.1 \%$ correct classification for 10 out of 11 heifers [96]. Altogether, remarkable differences exist in the abundances of genes expressed in the PWBC of heifers of differing fertility outcomes, and there is strong indication that these differences are useful as predictive tools for pregnancy outcome.

\section{Circulating miRNA profiles}

MicroRNAs (miRNAs) are a class of short, single stranded, non-coding RNAs that regulate gene expression post-transcription and impact several fundamental biological processes [97, 98]. While most of the functions are exerted within the cellular compartment, cells have the ability to export those molecules to the extracellular environment mostly packed within exosomes, microvesicles or associated with lipoprotein or protein complexes [99] and can be found in serum [100].

In an attempt to assess the predictive value of circulating miRNAs on first breeding season pregnancy outcome, we profiled small RNAs collected from plasma of 18 beef heifers on the day of fixed-time AI. One miRNA (miR-11995) was more abundant in plasma of AIpregnant heifers than not-pregnant heifers, while no differences in miRNA expression were detected between NB-pregnant and not-pregnant or AI-pregnant and NBpregnant heifers [96]. Such results indicate that expression profiles of miRNA alone may provide little indication of heifer fertility. A multilayered approach combining miRNA expression and relative coexpression with mRNA 
targets may be required to provide further insight into differences of replacement heifer fertility potential.

\section{Conclusion and future directions}

The selection and management of highly fertile replacement heifers will greatly impact the future success of the worldwide beef cattle industry. As technologies allow cattle producers to more effectively identify animals that are sub- or infertile, those animals can be managed as feeder cattle and eliminated from the replacement heifer pool earlier in their productive lifespan. Less capital will be lost on the development costs of infertile individuals, and heifer pregnancy rates early in the first breeding season can be improved.

Scientists must identify parameters beyond phenotypic traits and traditional genetic predictions to improve the producer's ability to retain only the most fertile individuals. While incorporation of AFC into replacement heifer evaluation may increase detection of lowly fertile animals, additional means to further determine heifer fertility potential must be identified. Single nucleotide polymorphism profiling of certain populations of animals has indicated potential genetic markers of fertility in heifers, however further understanding of differences in the transcription of mutated genes and their outcomes on heifer fertility beg for studies focused at the transcriptome and protein level. Recent studies have demonstrated remarkable differences in bloodborne mRNA of heifers with different reproductive outcome in their first breeding season. Most importantly, we have identified the potential for specific gene transcripts to be successfully utilized to classify heifers by pregnancy outcome.

Advancements of on the molecular phenotyping of fertile heifers at the systemic level may fill a gap in current understanding of the physiology of reduced fertility in beef heifers and form a basis from which additional studies aim to develop means to estimate fertility potential in beef heifers. It remains an important question, however, whether such biotechnology can be incorporated into cow-calf production systems and contribute to sustainable beef production.

\footnotetext{
Abbreviations

AFC: Antral follicle count; Al: Artificial insemination; ALAS2: 5'Aminolevulinate synthase 2; BTA: Bos taurus autosome; CIDR: Controlled internal drug release; Chr: Chromosome; cM: Centimorgan; CNKSR3: CNKSR family member 3; DEGs: Differentially expressed genes;

DNA: Deoxyribonucleic acid; EPD: Expected progeny difference; ESRRG: Estrogen-related receptor gamma; FABP4: Genes fatty acid binding protein 4; FDR: False discovery rate; GWAS: Genome wide association studies; kb: Kilobases; kg: Kilogram; KIF4A: Kinesin family member 4A; lb.: Pound; LOC: Locus; MBL-1: Mannose-binding lectin; MGA: Melengestrol acetate; miR: MicroRNA; miRNAs: MicroRNA; NAHMS: National Animal Health Monitoring System; NB: Natural breeding; NPV: Net present value; PAPPA: Pregnancy-associated plasma protein-A; PAPP-A2: Pregnancy-associated plasma protein-A2; PPP3CA: Protein phosphatase 3 catalytic subunit alpha; PWBC: Peripheral white blood cells; QTL: Quantitative trait loci;
}

RNA: Ribonucleic acid; SAXO2: Stabilizer of axonemal microtubules 2; SNPS: Single nucleotide polymorphisms; TAC3: Tachykinin Precursor 3; TAF1B: TATA-box binding protein associated factor, RNA polymerase I subunit B; TFF2: Trefoil factor 2; URB2: URB2 ribosome biogenesis homolog; USDA: United States Department of Agriculture; XKR4: Kell blood group complex subunit-related family

\section{Acknowledgements}

The authors appreciate the researchers that produced the results discussed in this review. We are thankful for valuable comments from Dr. Thomas Geary, Dr. Michael Smith and Dr. Russel Muntifering.

\section{Authors' contributions}

FHB conceived the review, SEM and FHB co-wrote the paper. The authors read and approved the final manuscript.

\section{Funding}

The Virginia Tech Open Access Subvention Fund contributed to the fee for article-processing charges.

\section{Availability of data and materials}

Data sharing is not applicable to this article as no datasets were generated or analyzed during the current study.

Ethics approval and consent to participate

There was no animal or sample handling for the production of this review.

\section{Consent for publication}

Not applicable.

\section{Competing interests}

The authors declare that they have no competing interests.

\section{Author details}

${ }^{1}$ Department of Animal Science, University of Tennessee, Knoxville, TN, USA. ${ }^{2}$ Department of Animal and Poultry Sciences, Virginia Polytechnic Institute and State University, 175 West Campus Drive, Blacksburg, VA 24061, USA.

Received: 23 March 2020 Accepted: 11 August 2020

Published online: 01 October 2020

\section{References}

1. Bellows DS, Ott SL, Bellows RA. Review: cost of reproductive diseases and conditions in cattle. Prof Anim Sci. 2002;18:26-32.

2. Lamb GC. Criteria for selecting replacements at weaning, before breeding, and after breeding. Vet Clin North Am Food Anim Pract. 2013;29:567-78.

3. BonDurant RH. Selected diseases and conditions associated with bovine conceptus loss in the first trimester. Theriogenology. 2007;68:461-73.

4. Larson RL, White BJ. Reproductive systems for north American beef cattle herds. Vet Clin North Am Food Anim Pract. 2016:32:249-66.

5. Houghton PL, Lemenager RP, Horstman LA, Hendrix KS, Moss GE. Effects of body composition, pre- and postpartum energy level and early weaning on reproductive performance of beef cows and preweaning calf gain. J Anim Sci. 1990;68:1438-46.

6. Bolormaa S, Pryce JE, Zhang Y, Reverter A, Barendse W, Hayes BJ, et al. Nonadditive genetic variation in growth, carcass and fertility traits of beef cattle. Genet Sel Evol. 2015;47:26.

7. Boyer CN, Griffith AP, DeLong KL. Reproductive failure and long-term profitability of spring- and fall-calving beef cows. J Agr Resour Econ. 2020; 45:78-91.

8. Mathews KH, Short SD. The beef cow replacement decision. J Agribus. 2001; 19:191-211.

9. Morris CA, Cullen NG. A note on genetic correlations between pubertal traits of males or females and lifetime pregnancy rate in beef cattle. Livest Prod Sci. 1994;39:291-7.

10. Mwansa PB, Kemp RA, Crews DH Jr, Kastelic JP, Bailey DRC, Coulter GH. Selection for cow lifetime pregnancy rate using bull and heifer growth and reproductive traits in composite cattle. Can J Anim Sci. 2000;80:507-10.

11. Cushman RA, Kill LK, Funston RN, Mousel EM, Perry GA. Heifer calving date positively influences calf weaning weights through six parturitions. J Anim Sci. 2013;91:4486-91. 
12. Bormann JM, Totir LR, Kachman SD, Fernando RL, Wilson DE. Pregnancy rate and first-service conception rate in Angus heifers. J Anim Sci. 2006;84:2022-5

13. Roberts AJ, Geary TW, Grings EE, Waterman RC, MacNeil MD. Reproductive performance of heifers offered ad libitum or restricted access to feed for a one hundred forty-day period after weaning. J Anim Sci. 2009;87:3043-52.

14. Peters SO, Kizilkaya K, Garrick DJ, Fernando RL, Reecy JM, Weaber RL, et al. Heritability and Bayesian genome-wide association study of first service conception and pregnancy in Brangus heifers. J Anim Sci. 2013;91:605-12.

15. Grings EE, Geary TW, Short RE, MacNeil MD. Beef heifer development within three calving systems. J Anim Sci. 2007:85:2048-58.

16. Funston RN, Deutscher GH. Comparison of target breeding weight and breeding date for replacement beef heifers and effects on subsequent reproduction and calf performance. J Anim Sci. 2004:82:3094-9.

17. Funston RN, Larson DM. Heifer development systems: dry-lot feeding compared with grazing dormant winter forage. J Anim Sci. 2011;89:1595-602.

18. Gutierrez K, Kasimanickam R, Tibary A, Gay JM, Kastelic JP, Hall JB, et al. Effect of reproductive tract scoring on reproductive efficiency in beef heifers bred by timed insemination and natural service versus only natural service. Theriogenology. 2014:81:918-24.

19. Martin JL, Creighton KW, Musgrave JA, Klopfenstein TJ, Clark RT, Adams DC, et al. Effect of prebreeding body weight or progestin exposure before breeding on beef heifer performance through the second breeding season. J Anim Sci. 2008;86:451-9.

20. Lynch JM, Lamb GC, Miller BL, Brandt RT, Cochran RC, Minton JE. Influence of timing of gain on growth and reproductive performance of beef replacement heifers. J Anim Sci. 1997;75:1715-22.

21. Mallory DA, Nash JM, Ellersieck MR, Smith MF, Patterson DJ. Comparison of long-term progestin-based protocols to synchronize estrus before fixedtime artificial insemination in beef heifers. J Anim Sci. 2011;89:1358-65.

22. Patterson DJ, Corrah LR, Kiracofe GH, Stevenson JS, Brethour JR. Conception rate in Bos Taurus and Bos Indicus crossbred heifers after postweaning energy manipulation and synchronization of estrus with melengestrol acetate and fenprostalene. J Anim Sci. 1989;67:1138-47.

23. Dickinson SE, Elmore MF, Kriese-Anderson L, Elmore JB, Walker BN, Dyce PW, et al. Evaluation of age, weaning weight, body condition score, and reproductive tract score in pre-selected beef heifers relative to reproductive potential. J Anim Sci Biotechnol. 2019;10:18.

24. Thomas JM, Locke JWC, Bishop BE, Abel JM, Ellersieck MR, Yelich JV, et al. Evaluation of the 14-d CIDR-PG and 9-d CIDR-PG protocols for synchronization of estrus in Bos indicus-influenced and Bos taurus beef heifers. Theriogenology. 2017;92:190-6.

25. Damiran D, Larson KA, Pearce LT, Erickson NE, Lardner BHA. Effect of calving period on beef cow longevity and lifetime productivity in western Canada. Transl Anim Sci. 2018:2:S61-S5.

26. Hughes H. Raised replacement heifers: some economic considerations. Vet Clin North Am Food Anim Pract. 2013;29:643-52.

27. Grings EE, Short RE, Klement KD, Geary TW, MacNeil MD, Haferkamp MR, et al. Calving system and weaning age effects on cow and preweaning calf performance in the northern Great Plains. J Anim Sci. 2005:83:2671-83.

28. Liu T, Mays AR, Turner KE, Wu JP, Brown MA. Relationships of milk yield and quality from six breed groups of beef cows to preweaning average daily gain of their calves1. J Anim Sci. 2015;93:1859-64.

29. Dickerson G. Efficiency of animal production-Molding the biological components. J Anim Sci. 1970;30:849-59.

30. Snelling WM, Golden BL, Bourdon RM. Within-herd genetic analyses of stayability of beef females. J Anim Sci. 1995;73:993-1001.

31. Funston RN, Musgrave JA, Meyer TL, Larson DM. Effect of calving distribution on beef cattle progeny performance. J Anim Sci. 2012;2012:5118-21.

32. Patterson DJ, Thomas JM, Martin NT, Nash JM, Smith MF. Control of estrus and ovulation in beef heifers. Vet Clin North Am Small Anim Pract. 2013;29: 591-617.

33. Freetly HC, Cundiff LV. Postweaning growth and reproduction characteristics of heifers sired by bulls of seven breeds and raised on different levels of nutrition. J Anim Sci. 1997;75:2841-51.

34. Freetly HC, Kuehn LA, Cundiff LV. Growth curves of crossbred cows sired by Hereford, Angus, Belgian blue, Brahman, Boran, and Tuli bulls, and the fraction of mature body weight and height at puberty. J Anim Sci. 2011;89: 2373-9.

35. Cardoso RC, Alves BRC, Prezotto LD, Thorson JF, Tedeschi LO, Keisler DH, et al. Use of a stair-step compensatory gain nutritional regimen to program the onset of puberty in beef heifers. J Anim Sci. 2014;92:2942-9.
36. Gunn PJ, Schoonmaker JP, Lemenager RP, Bridges GA. Feeding distiller's grains as an energy source to gestating and lactating beef heifers: impact on female progeny growth, puberty attainment, and reproductive processes. J Anim Sci. 2015:93:746-57.

37. Byerley DJ, Staigmiller RB, Berardinelli JG, Short RE. Pregnancy rates of beef heifers bred either on puberal or third estrus. J Anim Sci. 1987;65:645-50.

38. Roberts AJ, Ketchum JN, Funston RN. Developmental and reproductive characteristics of beef heifers classified by number of estrous cycles experienced by start of first breeding. Transl Anim Sci. 2018;3:541-8.

39. Patterson DJ, Perry RC, Kiracofe GH, Bellows RA, Staigmiller RB, Corah LR. Management considerations in heifer development and puberty. J Anim Sci. 1992;70:4018-35.

40. Day ML, Imakawa K, Garcia-Winder M, Zalesky DD, Schanbacher BD, Kittok $\mathrm{RJ}$, et al. Endocrine mechanisms of puberty in heifers: Estradiol negative feedback regulation of luteinizing hormone secretion. Biol Reprod. 1984;31: 332-41.

41. Gonzalez-Padilla E, Wiltbank JN, Niswender GD. Puberty in beef heifers. I. the interrelationship between pituitary, hypothalamic and ovarian hormones. J Anim Sci. 1975:40:1091-104.

42. Rae DO, Kunkle WE, Chenoweth PJ, Sand RS, Tran T. Relationship of parity and body condition score to pregnancy rate in Florida beef-cattle. Theriogenology. 1993;39:1143-52.

43. Milagres JC, Dillard EU, Robinson OW. Influences of age and early growth on reproductive performance of yearling Hereford heifers. J Anim Sci. 1979; 48:1089-95.

44. Fleck AT, Schalles RR, Kiracofe GH. Effect of growth rate through 30 months on reproductive performance of beef heifers. J Anim Sci. 1980:51:816-21.

45. Clanton DC, Jones LE, England ME. Effect of rate and time of gain after weaning on the development of replacmeent beef heifers. J Anim Sci. 1983; 56:280-5.

46. Grings EE, Staigmiller RB, Short RE, Bellows RA, MacNeil MD. Effects of stair step nutrition and trace mineral supplementation on attainment of puberty in beef hefiers of three sire breeds. J Anim Sci. 1999;77:810-5.

47. Martin LC, Brinks JS, Bourdon RM, Cundiff LV. Genetic effects on beef heifer puberty and subsequent reproduction. J Anim Sci. 1992;70:4006-17.

48. Mulliniks JT, Hawkins DE, Kane KK, Cox SH, Torell LA, Scholljegerdes EJ, et al. Metabolizable protein supply while grazing dormant winter forage during heifer development alters pregnancy and subsequent in-herd retention rate. J Anim Sci. 2013;91:1409-16.

49. Anderson KJ, Lefever DG, Brinks JS, Odde KG. The use of reproductive tract scoring in beef heifers. Agri Pract. 1991;12:19-26.

50. Holm DE, Thompson PN, Irons PC. The value of reproductive tract scoring as a predictor of fertility and production outcomes in beef heifers. J Anim Sci. 2009;87:1934-40.

51. Gonzalez-Padilla E, Ruiz R, LeFever D, Denham A, Wiltbank JN. Puberty in beef heifers. III. Induction of fertile estrus. J Anim Sci. 1975;40:1110-8.

52. Short RE, Bellows RA, Carr JB, Staigmiller RB, Randel RD. Induced or synchronized puberty in heifers. J Anim Sci. 1976;43:1254-8.

53. Berardinelli JG, Dailey RA, Butcher RL, Inskeep EK. Source of progesterone prior to puberty in beef heifers. J Anim Sci. 1979;49:1276-80.

54. Imwalle DB, Patterson DJ, Schillo KK. Effects of melengestrol acetate on onset of puberty, follicular growth, and patterns of luteinizing hormone secretion in beef heifers. Biol Reprod. 1998;58:1432-6.

55. Hall JB, Staigmiller RB, Short RE, Bellows RA, MacNeil MD, Bellows SE. Effect of age and pattern of gain on induction of puberty with a progestin in beef heifers. J Anim Sci. 1997;75:1606-11.

56. Tanaka Y, Vincent DL, Ledgerwood KS, Weems CW. Variable progesterone response and estradiol secretion in prepubertal beef heifers following treatment with norgestomet implants. Theriogenology. 1995;43:1077-86.

57. Lucy MC, Billings HJ, Butler WR, Ehnis LR, Fields MJ, Kesler DJ, et al. Efficacy of an intravaginal progesterone insert and an injection of PGF2a for synchronizing estrus and shortening the interval to pregnancy in postpartum beef cows, peripubertal beef heifers, and dairy heifers. J Anim Sci. 2001;79:982-95.

58. Patterson DJ, Corah LR, Brethour JR. Response of prepubertal Bostaurus and Bosindicus $\times$ Bostaurus heifers to melengestrol acetate with or without gonadotropin-releasing hormone. Theriogenology. 1990;33:661-8.

59. Moriel P, Lancaster P, Lamb GC, Vendramini JMB, Arthington JD. Effects of post-weaning growth rate and puberty induction protocol on reproductive performance of Bos indicus-influenced beef heifers. J Anim Sci. 2017:95: 3523-31. 
60. Torres-Vázquez JA, van der Werf JHJ, Clark SA. Genetic and phenotypic associations of feed efficiency with growth and carcass traits in Australian Angus cattle. J Anim Sci. 2018;96:4521-31.

61. Fortes MRS, Snelling WM, Reverter A, Nagaraj SH, Lehnert SA, Hawken RJ, et al. Gene network analyses of first service conception in Brangus heifers: use of genome and trait associations, hypothalamic-transcriptome information, and transcription factors. J Anim Sci. 2012;2012:2894-906.

62. Peters SO, Kizilkaya K, Garrick DJ, Fernando RL, Reecy JM, Weaber RL, et al. Bayesian genome-wide association analysis of growth and yearling ultrasound measures of carcass traits in Brangus heifers. J Anim Sci. 2012;90: 3398-409.

63. Doyle SP, Golden BL, Green RD, Brinks JS. Additive genetic parameter estimates for heifer pregnancy and subsequent reproduction in Angus females. J Anim Sci. 2000;78:2091-8.

64. Toghiani S, Hay E, Sumreddee P, Geary TW, Rekaya R, Roberts AJ. Genomic prediction of continuous and binary fertility traits of females in a composite beef cattle breed. J Anim Sci. 2017;95:4787-95.

65. McAllister CM, Speidel SE, Crews DH Jr, Enns RM. Genetic parameters for intramuscular fat percentage, marbling score, scrotal circumference, and heifer pregnancy in red Angus cattle. J Anim Sci. 2011;89:2068-72.

66. Boddhireddy P, Kelly MJ, Northcutt S, Prayaga KC, Rumph J, DeNise S. Genomic predictions in Angus cattle: comparisons of sample size, response variables, and clustering methods for cross-validation. J Anim Sci. 2014;92: 485-97.

67. Cundiff LV, Gregory KE, Koch RM. Effects of heterosis on reproduction in Hereford, Angus and Shorthorn cattle. J Anim Sci. 1974;38:711-27.

68. MacNeil MD, Dearborn DD, Cundiff LV, Dinkel CA, Gregory KE. Effects of inbreeding and heterosis in Hereford females on fertility, calf survival and preweaning growth. J Anim Sci. 1989;67:895-901.

69. Cushman RA, McNeel AK, Freetly HC. The impact of cow nutrient status during the second and third trimesters on age at puberty, antral follicle count, and fertility of daughters. Livest Sci. 2014;162:252-8.

70. Cushman RA, Allan MF, Kuehn LA, Snelling WM, Cupp AS, Freetly HC. Evaluation of antral follicle count and ovarian morphology in crossbred beef cows: investigation of influence of stage of the estrous cycle, age, and birth weight. J Anim Sci. 2009;87:1971-80.

71. Tanaka Y, Nakada K, Moriyoshi M, Sawamukai Y. Appearance and number of follicles and change in the concentration of serum FSH in female bovine fetuses. Reproduction. 2001;121:777-82.

72. Burkhart MN, Juengel JL, Smith PR, Heath DA, Perry GA, Smith MF, et al. Morphological development and characterization of aromatase and estrogen receptors alpha and beta in fetal ovaries of cattle from days 110 to 250. Anim Reprod Sci. 2010;117:43-54.

73. Sirois J, Fortune JE. Ovarian follicular dynamics during the estrous cycle in heifers monitored by real-time ultrasonograph. Biol Reprod. 1988:39:308-17.

74. Burns DS, Jimenez-Krassel F, Ireland JL, Knight PG, Ireland JJ. Numbers of antral follicles during follicular waves in cattle: evidence for high variation among animals, very high repeatability in individuals, and an inverse association with serum follicle-stimulating hormone concentrations. Biol Reprod. 2005;73:54-62.

75. Ireland JL, Scheetz D, Jimenez-Krassel F, Themmen AP, Ward F, Lonergan P, et al. Antral follicle count reliably predicts number of morphologically healthy oocytes and follicles in ovaries of young adult cattle. Biol Reprod. 2008;79:1219-25.

76. Mossa F, Carter F, Walsh SW, Kenny DA, Smith GW, Ireland JL, et al. Maternal undernutrition in cows impairs ovarian and cardiovascular systems in their offspring. Biol Reprod. 2013;88:92.

77. Jimenez-Krassel F, Scheetz DM, Neuder LM, Ireland JL, Pursley JR, Smith GW, et al. Concentration of anti-Mullerian hormone in dairy heifers is positively associated with productive herd life. J Dairy Sci. 2015;98:3036-45.

78. Hawken RJ, Zhang YD, Fortes MRS, Collis E, Barris WC, Corbet NJ, et al. Genome-wide association studies of female reproduction in tropically adapted beef cattle. J Anim Sci. 2012;90:1398-410.

79. Fortes MRS, Lehnert SA, Bolormaa S, Reich C, Fordyce G, Corbet NJ, et al. Finding genes for economically important traits: Brahman cattle puberty. Anim Prod Sci. 2012;52:143-50.

80. McDaneld TG, Kuehn LA, Thomas MG, Snelling WM, Smith TPL, Pollak EJ, et al. Genomewide association study of reproductive efficiency in female cattle. J Anim Sci. 2014;2014:1945-57.

81. McDaneld TG, Kuehn LA, Thomas MG, Snelling WM, Sonstegard TS, Matukumalli LK, et al. $Y$ are you not pregnant: identification of $Y$ chromosome segments in female cattle with decreased reproductive efficiency. J Anim Sci. 2012;90:2142-51.

82. Neupane M, Geary TW, Kiser JN, Burns GW, Hansen PJ, Spencer TE, et al. Loci and pathways associated with uterine capacity for pregnancy and fertility in beef cattle. PLoS One. 2017;12:e0188997.

83. Salilew-Wondim D, Holker M, Rings F, Ghanem N, Ulas-Cinar M, Peippo J, et al. Bovine pretransfer endometrium and embryo transcriptome fingerprints as predictors of pregnancy success after embryo transfer. Physiol Genomics. 2010;42:201-18.

84. de Camargo GM, Costa RB, de Albuquerque LG, Regitano LC, Baldi F, Tonhati H. Association between JY-1 gene polymorphisms and reproductive traits in beef cattle. Gene. 2014;533:477-80.

85. Dias MM, Souza FR, Takada L, Feitosa FL, Costa RB, Diaz ID, et al. Study of lipid metabolism-related genes as candidate genes of sexual precocity in Nellore cattle. Genet Mol Res. 2015;14:234-43.

86. Irano N, de Camargo GM, Costa RB, Terakado AP, Magalhaes AF, Silva RM, et al. Genome-wide association study for indicator traits of sexual precocity in Nellore cattle. PLoS One. 2016;11:e0159502.

87. Junior GAO, Perez BC, Cole JB, Santana MHA, Silveira J, Mazzoni G, et al. Genomic study and medical subject headings enrichment analysis of early pregnancy rate and antral follicle numbers in Nelore heifers. J Anim Sci. 2017;95:4796-812

88. Takada L, Barbero MMD, Oliveira HN, de Camargo GMF, Fernandes Junior GA, Aspilcueta-Borquis RR, et al. Genomic association for sexual precocity in beef heifers using pre-selection of genes and haplotype reconstruction. PLoS One. 2018;13:e0190197.

89. Hu ZL, Park CA, Reecy JM. Building a livestock genetic and genomic information knowledgebase through integrative developments of animal QTLdb and CorrDB. Nucleic Acids Res. 2019;47:D701-10.

90. Regatieri IC, Boligon AA, Costa RB, de Souza FRP, Baldi F, Takada L, et al. Association between single nucleotide polymorphisms and sexual precocity in Nellore heifers. Anim Reprod Sci. 2017;177:88-96.

91. Marigorta UM, Rodriguez JA, Gibson G, Navarro A. Replicability and prediction: lessons and challenges from GWAS. Trends Genet. 2018;34:504-17.

92. Garrett-Bakelman FE, Darshi M, Green SJ, Gur RC, Lin L, Macias BR, et al. The NASA Twins Study: A multidimensional analysis of a year-long human spaceflight. Science. 2019;364:eaau8650.

93. Scalici E, Mullet T, Ferrieres Hoa A, Gala A, Loup V, Anahory T, et al. Circulating nucleic acids and infertility. Gynecol Obstet Fertil. 2015;43:593-8.

94. Li-Pook-Than J, Snyder M. iPOP goes the world: integrated personalized Omics profiling and the road toward improved health care. Chem Biol. 2013;20:660-6.

95. Dickinson SE, Griffin BA, Elmore MF, Kriese-Anderson L, Elmore JB, Dyce PW, et al. Transcriptome profiles in peripheral white blood cells at the time of artificial insemination discriminate beef heifers with different fertility potential. BMC Genomics. 2018;19:129.

96. Moorey SE, Walker BN, Elmore MF, Elmore JB, Rodning SP, Biase FH. Rewiring of gene expression in circulating white blood cells is associated with pregnancy outcome in heifers (Bos taurus). bioRxiv. 2020. https://doi. org/10.1101/2020.03.18.997379.

97. O'Brien J, Hayder H, Zayed Y, Peng C. Overview of microRNA biogenesis, mechanisms of actions, and circulation. Front Endocrinol. 2018;9:402.

98. Gebert LFR, MacRae IJ. Regulation of microRNA function in animals. Nat Rev Mol Cell Biol. 2019;20:21-37.

99. Sohel MH. Extracellular/circulating microRNAs: release mechanisms, functions and challenges. Achiev Life Sci. 2016;10:175-86.

100. Arroyo JD, Chevillet JR, Kroh EM, Ruf IK, Pritchard CC, Gibson DF, et al. Argonaute2 complexes carry a population of circulating microRNAs independent of vesicles in human plasma. P Natl Acad Sci USA. 2011;108: 5003-8. 